\title{
Immobilization of Yarrowia lipolytica Lipase on Macroporous Resin Using Different Methods: Characterization of the Biocatalysts in Hydrolysis Reaction
}

\author{
Jingjing Sun, Yiling Chen, Jun Sheng, and Mi Sun \\ Laboratory of Enzyme Engineering, Yellow Sea Fisheries Research Institute, Chinese Academy of Fishery Sciences, \\ Qingdao 266071, China \\ Correspondence should be addressed to Mi Sun; sunmi0532@yahoo.com
}

Received 4 May 2015; Revised 19 June 2015; Accepted 21 June 2015

Academic Editor: Denise Freire

Copyright (C) 2015 Jingjing Sun et al. This is an open access article distributed under the Creative Commons Attribution License, which permits unrestricted use, distribution, and reproduction in any medium, provided the original work is properly cited.

\begin{abstract}
To improve the reusability and organic solvent tolerance of microbial lipase and expand the application of lipase (hydrolysis, esterification, and transesterification), we immobilized marine microbial lipase using different methods and determined the properties of immobilized lipases. Considering the activity and cost of immobilized lipase, the concentration of lipase was fixed at $2 \mathrm{mg} / \mathrm{mL}$. The optimal temperature of immobilized lipases was $40^{\circ} \mathrm{C}$ and $5^{\circ} \mathrm{C}$ higher than free lipase. The activities of immobilized lipases were much higher than free lipase at alkaline $\mathrm{pH}$ (more than $50 \%$ at $\mathrm{pH} 12$ ). The free lipase lost most activity (35.3\%) and immobilized lipases retained more than $46.4 \%$ of their initial activity after $3 \mathrm{~h}$ heat treatment at $70^{\circ} \mathrm{C}$. At alkaline $\mathrm{pH}$, immobilized lipases were more stable than free lipase (more than $60 \%$ residue activity at $\mathrm{pH} 11 \mathrm{for} 3 \mathrm{~h}$ ). Immobilized lipases retained $80 \%$ of their activity after 5 cycles and increased enzyme activity (more than 108.7\%) after $3 \mathrm{~h}$ treatment in tert-butanol. Immobilization of lipase which improved reusability of lipase and provided a chance to expand the application of marine microbial lipase in organic system expanded the application range of lipase to catalyze hydrolysis and esterification in harsh condition.
\end{abstract}

\section{Introduction}

Lipases (triacylglycerol hydrolases, E.C. 3.1.1.3) are enzymes that catalyze the hydrolysis of long chain triglycerides under physiological conditions [1-3]. They also can accept a broad range of substrates and catalyze interesterification [4-6] and esterification [3]. Lipases have some good characteristics such as high tolerance of the environment $(\mathrm{pH}$, temperature, and organic solvents), require no cofactor for reaction, and are widely used on biological catalysis [7] such as biodiesel production [8-10], biopolymer synthesis [11], enantiopure synthesis of pharmaceuticals [12, 13], laundry formulations [14], and food chemistry [15].

Compared with chemical catalyst, the costs of separation and purification of enzyme are huge. Immobilization of enzyme can expand the application of biocatalysis technology and allow enzymes to easily separate from reaction mixture and recycle for next reaction. Furthermore, immobilization of enzyme can increase its thermal and chemical stability and resistance to extreme changes in conditions [16-18]. Lipases are very suitable to immobilization and propitious to industry application [19-23]. There are many immobilized methods for enzymes and the commonly used methods are physical adsorption, entrapment, cross-linkage, and covalent attachment [24]. Physical adsorption method can be achieved by mixing enzyme solution and solid support for a period of time and then removing unabsorbed enzyme by washing with buffer [25-29]. Advantages of adsorption method are easy operation, saving time, maintaining the enzyme activity, and being more economic. But it may not be strong enough and the enzymes probably fall off during washing and operation [30]. Entrapment method is trapped enzyme in insoluble beads or microspheres but this insoluble carrier may block the substrates in and the product out [31]. Cross-linkage method is to covalently bond enzymes together to create aggregates. The reaction may cover the active site of enzyme and block the substrate close to enzyme in space. Covalent attachment method is one of the most stabilized ways 

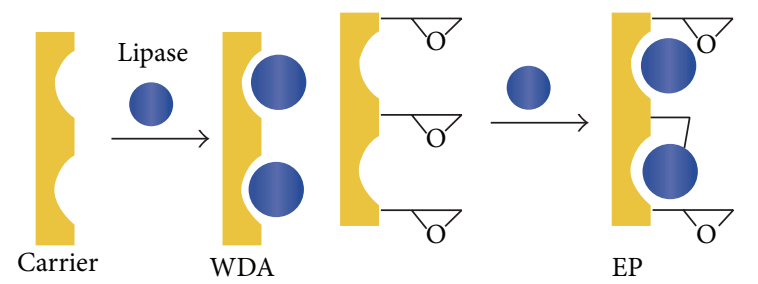

(a)

(b)
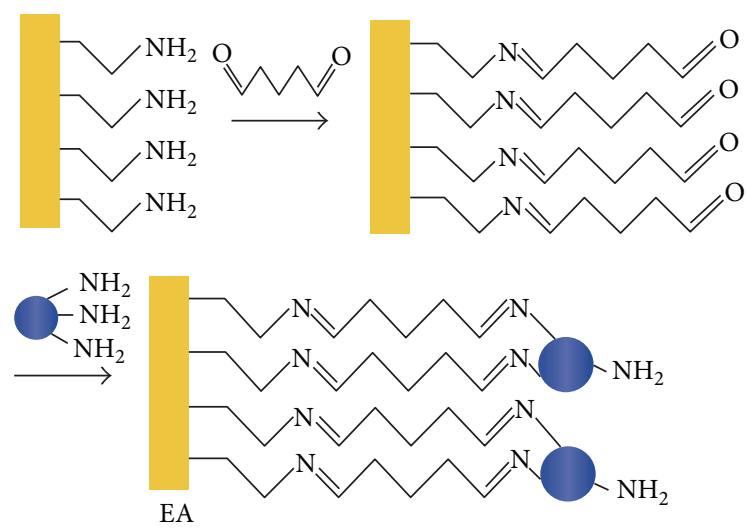

(c)

FIGURE 1: Principles of lipase immobilization: (a) macroporous resin (WDA); (b) support with epoxy group (EP); (c) support with amino group (EA).

between enzyme and support. Covalent attachment method is a commonly used method for immobilization of enzymes. It can be implemented by connected enzyme and support by covalent linkage $[32,33]$. There are couples of active sites in the enzyme, such as $\varepsilon$-amino group of lysine, thiol group of cysteine, carboxyl group of glutamate, and iminazole of histidine. These active groups are direct or through spacer arm attached to the functional groups of carrier (e.g., aldehyde group, carbodiimide, or maleinimide). However, the covalent attachment may reduce the activity of enzyme because of the inflexible linkage between enzyme and carrier [34].

In this work, our attention focused on the immobilization and biochemical characteristics of Yarrowia lipolytica lipase [35]. This lipase was cloned from Yarrowia lipolytica (Bohaisea-9145) and expressed in Escherichia coli. The optimal temperature and $\mathrm{pH}$ of the purified lipase to $p$ nitrophenyl laurate were $35^{\circ} \mathrm{C}$ and 8.5 . The process of immobilization enzyme is complex, and single method may not be the appropriate one. So we compared three immobilization methods with different principles (Figure 1): macroporous resin (adsorption), support with epoxy group (adsorption and covalent attachment), and activated aminated support with glutaraldehyde (covalent attachment). The first immobilization method is based on the absorption of macroporous material. The epoxy-activated carrier can slowly multipointedly covalently attach to nucleophiles on the enzyme (e.g., amino, thiol, and hydroxyl groups) after adsorption [36, 37]. Activation of aminated carrier with glutaraldehyde could form Schiff bases with amine groups of enzyme and achieve multipoint covalent attachment [38-40].

\section{Material and Methods}

2.1. Materials. Lyophilized powder of marine Yarrowia lipolytica yeast lipase from our laboratory was used. WDA918 (macroporous acrylic acid series weakly acidic cation exchange resin) was purchased from Anhui Wandong Chemical Co., Ltd., China. LX-1000EP (epoxy resin) and LX1000EA (amino resin) were acquired from Xian Lanxiao Technology Co., Ltd., China. Glutaraldehyde AR (50\% in $\mathrm{H}_{2} \mathrm{O}$ ) was purchased from Aladdin Industrial Inc. Tris(hydroxymethyl)aminomethane (Tris) was from Amresco Co. $P$-Nitrophenyl laurate was purchased from Sigma-Aldrich. Ultrapure water generated through a UNIQUE-S15 facility was used throughout the experiments.

2.2. Preparation of Lipase. Yarrowia lipolytica lipase was cloned in expression vector pET-21a $(+)$ with a C-terminal His-tag and expressed in Escherichia coli BL21 (DE3). The transformants were cultured at $37^{\circ} \mathrm{C}$ in $\mathrm{LB}$ medium supplemented with $100 \mu \mathrm{g} / \mathrm{mL}$ ampicillin until an OD600 of $0.4-$ 0.6 was reached. IPTG was added to the medium at a final concentration of $0.5 \mathrm{mM}$. The cells were further cultured at $16^{\circ} \mathrm{C}$ for $12 \mathrm{~h}$. The recombinant lipase was purified using a Niaffinity column according to the manufacturer's protocol. The final product was freeze-dried for $12 \mathrm{~h}$. The activity protein concentration $(0.1 \mathrm{mg} / \mathrm{mL})$ was $21.8 \mathrm{U} / \mathrm{mL}$.

2.3. Immobilization of Lipase. To remove contaminants and keep proper $\mathrm{pH}$ of the surface, WDA918 and LX-1000EP $(10 \mathrm{~g})$ were separately treated by $40 \mathrm{~mL} 0.1 \mathrm{M} \mathrm{pH} 8.0$ potassium phosphate buffer for $1 \mathrm{~h}$ and then freeze-dried for $8 \mathrm{~h}$. Add lipase solution ( $40 \mathrm{~mL} 0.02 \mathrm{M} \mathrm{pH} 8$ potassium phosphate buffer) to prepared WDA918 (10 g) or LX-1000EP (10 g). The mixture was at $25^{\circ} \mathrm{C}$ and shake speed was $180 \mathrm{rpm}$ for $12 \mathrm{~h}$. Then remove extra lipase and freeze-dry for $8 \mathrm{~h}$. The immobilization products of WDA918 and LX-1000EP were named, respectively, WDA and EP.

LX-1000EA was treated by $40 \mathrm{~mL} 0.1 \mathrm{M} \mathrm{pH} 8$ potassium phosphate buffer for $1 \mathrm{~h}$ and then freeze-dried for 8 h. Glutaraldehyde solution $(2.5 \%, 0.02 \mathrm{M} \mathrm{pH} 8$ potassium phosphate buffer) was added into the prepared LX-1000EA and reacted overnight. Then remove extra glutaraldehyde and freeze-dry for $8 \mathrm{~h}$. Lipase solution $(40 \mathrm{~mL} 0.02 \mathrm{M} \mathrm{pH} 8$ potassium phosphate buffer) and the glutaraldehyde-treated LX1000EA (10 g) were mixed together at $25^{\circ} \mathrm{C}$ and shake speed was $180 \mathrm{rpm}$ for $12 \mathrm{~h}$. Then remove extra lipase and freezedry for $8 \mathrm{~h}$. The immobilization product of LX-1000EA was named EA.

2.4. Lipase Activity Assay. There are two solutions that were prepared before the lipase activity assay: solution A ( $83 \mathrm{mg}$ of p-nitrophenyl laurate was dissolved in $25 \mathrm{~mL}$ of isopropanol) and solution $\mathrm{B}(100 \mathrm{mM}$ potassium phosphate buffer; $\mathrm{pH} 8$; $0.5 \%$ Triton $\mathrm{X}-100)$. Lipase $(0.1 \mathrm{~mL})$ solution or immobilized lipase was added to $1.5 \mathrm{~mL}$ solution $\mathrm{B}$ and $0.1 \mathrm{~mL}$ solution $\mathrm{A}$. We mix up the mixture gently and the mixture was incubated for $8 \mathrm{~min}$ in a shaking water bath at $40^{\circ} \mathrm{C}$. The inactivated lipase $(0.1 \mathrm{~mL})$ or inactivated immobilized lipase (heated at $100^{\circ} \mathrm{C}$ for $5 \mathrm{~min}$ ) was used as control. Then, the reactions 
were terminated by putting the mixtures in ice and the OD (optical density) value at $410 \mathrm{~nm}$ of mixtures was read by spectrophotometer. One unit (U) of enzyme activity was defined as the amount of enzyme required for the liberation of $1 \mu \mathrm{mol} p$-nitrophenol per minute under the assay conditions.

2.5. Effect of Lipase Concentration on Immobilization. Concentration gradients of lipase solutions $(0.5,1,2,4$, and $6 \mathrm{mg} / \mathrm{mL} 0.02 \mathrm{M} \mathrm{pH} 8$ potassium phosphate buffer) of $0.8 \mathrm{~mL}$ were incubated with $200 \mathrm{mg}$ WDA918, LX-1000EP, or glutaraldehyde-treated LX-1000EA. Concentration gradients of lipase solutions were treated at the same condition as control. The enzyme activity of supernatants and control was assayed by the method which was described before. The relation between the percentages of bounding lipase and lipase concentration was calculated.

2.6. Optimal Temperature and $p H$ of Immobilized Enzyme. The activity of immobilized enzyme $(50 \mathrm{mg})$ or lipase $(100 \mu \mathrm{L})$ was assayed in potassium phosphate buffer $(100 \mathrm{mM}$, $\mathrm{pH} 8$ ) at different temperatures $20,30,35,40,50,60$, and $70^{\circ} \mathrm{C}$. The activity of immobilized enzyme $(50 \mathrm{mg})$ or lipase $(100 \mu \mathrm{L})$ was assayed in potassium phosphate buffer $(\mathrm{pH} 7,8)$ and tris- $\mathrm{HCl}$ buffer ( $\mathrm{pH} 9,10,11$, and 12$)$ at $40^{\circ} \mathrm{C}$.

\subsection{Temperature and pH Stability of Immobilized Enzyme.} The thermal stability of immobilized enzyme or lipase was investigated by incubating the immobilized enzyme or lipase at $20,30,35,40,50,60$, and $70^{\circ} \mathrm{C}$ for $3 \mathrm{~h}$ in a water bath. The $\mathrm{pH}$ stability of immobilized enzyme or lipase was investigated by incubating the immobilized enzyme or lipase at different $\mathrm{pH}(7,8,9,10,11$, and 12$)$ for $3 \mathrm{~h}$ at room temperature.

2.8. Reusability of Immobilized Enzyme. Immobilized enzyme was assayed at $40^{\circ} \mathrm{C}$ for $8 \mathrm{~min}$ and washed three times using solution B. Repeat this process for 10 times and read the $O D$ value of mixtures at $410 \mathrm{~nm}$ by spectrophotometer.

2.9. Effect of Organic Solvents on Immobilized Lipase Activity. The effect of various organic solvents (methanol, ethanol, acetone, chloroform, $\mathrm{n}$-hexane, $\mathrm{n}$-heptane, and tert-butanol) on immobilized enzyme was determined. The immobilized lipase was incubated with each of the selected solvents at room temperature for $3 \mathrm{~h}$. Then the organic solvents were removed and the residual activity of immobilized lipases was determined.

\section{Results and Discussion}

3.1. Immobilization of Microbial Lipase. It is important to choose a proper immobilization method for enzyme. Bounding ability of carrier which is determined by residue activity of enzyme solution is one of the most important index immobilizations of enzyme. Different carriers perform different effects between protein concentration and bounding efficiency (Figure 2). When the protein concentration is between $0.5 \mathrm{mg} / \mathrm{mL}$ and $2 \mathrm{mg} / \mathrm{mL}$, WDA performed with the highest bounding efficiency (more than 80\%) compared to other carriers. With increasing protein concentration from

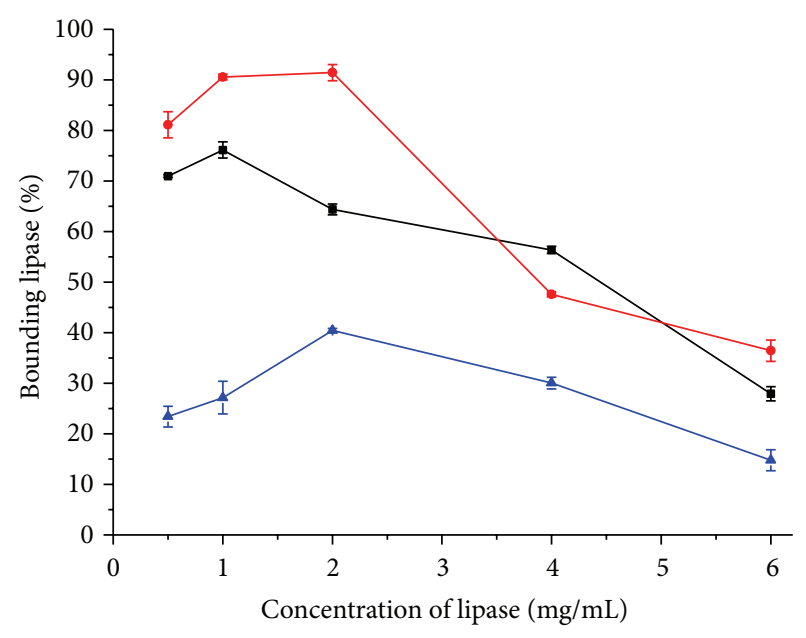

FIGURE 2: Effect of protein concentration on immobilization of lipase. This figure illustrated the relationship between the percentages of bounding lipase and lipase concentration. The color of curves represents the following: red: WDA; black: EP; blue: EA.

$4 \mathrm{mg} / \mathrm{mL}$ to $6 \mathrm{mg} / \mathrm{mL}$, the bounding efficiency of these three immobilization methods was almost at the same level (less than $60 \%$ ) because of the carrier capacity. The bounding efficiency of EA was the lowest one because covalent attachment efficiency between lipase and carrier may limit the bounding opportunity of lipase. For activation of aminated carrier with glutaraldehyde (EA), the number of active groups on the surface of the carrier was fixed. When the concentration of protein was high, there were insufficient active groups for amino groups of lipase resulting in decreased modification rate $[39,41,42]$. Effect of protein concentration on immobilization of lipase is showed in Figure 3. When the protein concentration was more than $2 \mathrm{mg} / \mathrm{mL}$, the activity of WDA and EP reached a plateau and EA increased steadily. Considering the activity of immobilization enzyme and cost of lipase and carrier, the concentration of lipase was fixed at $2 \mathrm{mg} / \mathrm{mL}$.

3.2. Effect of Temperature and $p H$ on Activity of Free and Immobilized Lipase. The optimal temperature on the activities of the free and immobilized lipase was investigated in the temperature range $20-70^{\circ} \mathrm{C}$. The results are given in Figure 4 . The optimal temperature of immobilized lipase was $40^{\circ} \mathrm{C}$ and $5^{\circ} \mathrm{C}$ higher than free lipase, because thermal stability of lipase was enhanced after immobilization. The activity of immobilized lipase kept more than $50 \%$ at $70^{\circ} \mathrm{C}$.

The effect of $\mathrm{pH}$ on the activity of free and immobilized lipase in $p$-nitrophenyl laurate hydrolysis was determined in the $\mathrm{pH}$ range 7-12 and the results are presented in Figure 5. Optimal $\mathrm{pH}$ value of free lipase and immobilized lipases was obtained at $\mathrm{pH}$ 9. The activity of immobilized lipase was much higher than the free lipase at neutral and alkaline $\mathrm{pH}$ especially at alkaline $\mathrm{pH}$ (more than $50 \%$ at $\mathrm{pH} 12$ ). Immobilization expanded the application range of lipase to catalyze hydrolysis and esterification in harsh condition.

3.3. Temperature and pH Stability of Immobilized Enzyme. The thermal stability on the activities of the free and 


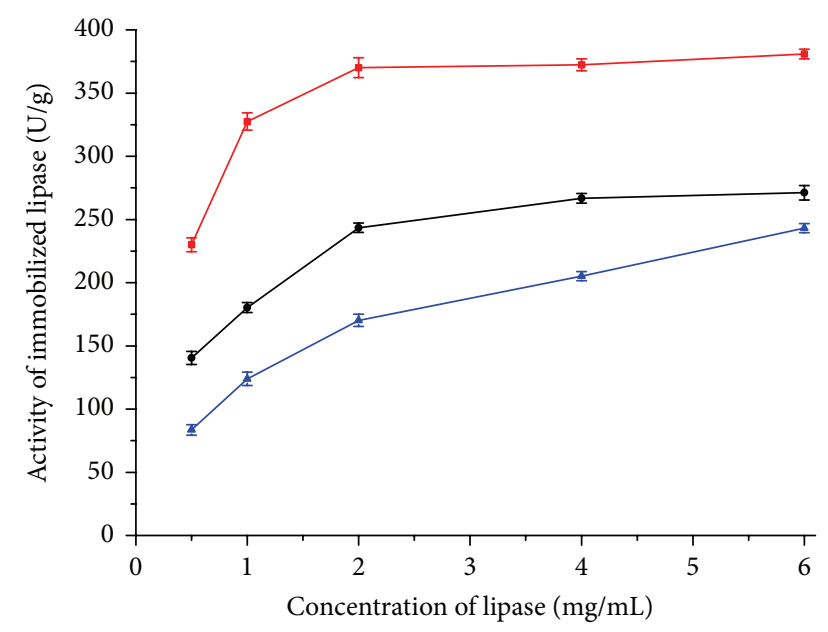

FIGURE 3: Effect of protein concentration on immobilization of lipase. This figure illustrated the relationship between the activity of immobilized lipase and lipase concentration. The color of curves represents the following: red: WDA; black: EP; blue: EA.

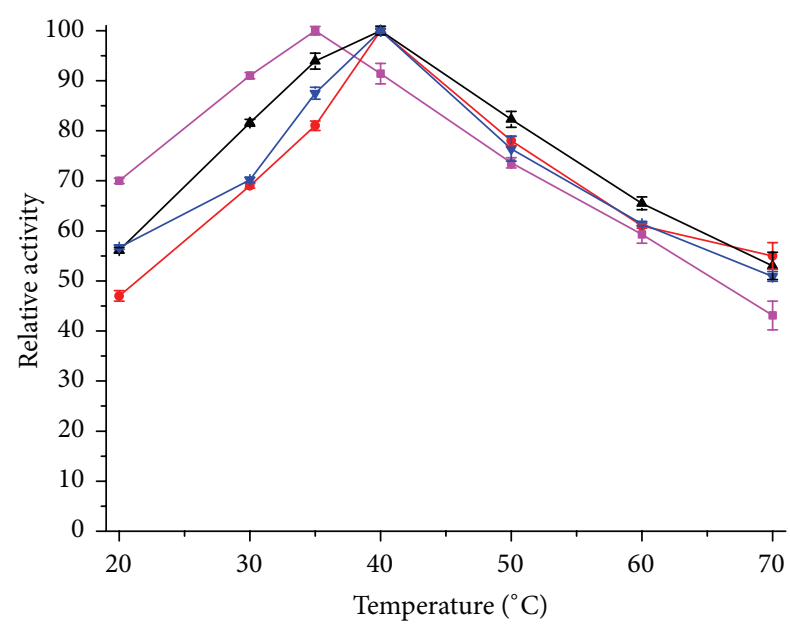

FIGURE 4: Optimal temperature of immobilized enzyme. This figure shows the relationship between relative activity and temperature. The absolute values of hydrolytic activity: free lipase: $24.3 \mathrm{U} / \mathrm{mL}$; WDA: $350.1 \mathrm{U} / \mathrm{g}$; EP: $240.3 \mathrm{U} / \mathrm{g}$; EA: $169.9 \mathrm{U} / \mathrm{g}$. The color of curves represents the following: magenta: free lipase; red: WDA; black: EP; blue: EA.

immobilized lipase was investigated in the temperature range $20-70^{\circ} \mathrm{C}$ for $3 \mathrm{~h}$. Results shown in Figure 6 indicate that immobilized lipases are much more stable than free lipase at elevated temperatures. At $60^{\circ} \mathrm{C}$, free enzyme retained $49 \%$ of its initial activity after a $3 \mathrm{~h}$ of heat treatment and immobilized lipases kept greater than $62.4 \%$ activity. At $70^{\circ} \mathrm{C}$, the free enzyme lost most activity (35.3\%) and immobilized lipases retained more than $46.4 \%$ of their initial activity after a $3 \mathrm{~h}$ of heat treatment. Thermal stability of enzyme is greatly enhanced after immobilization, because the carriers may provide an external backbone to keep enzyme's shape which minimizes the negative effect of high temperature.

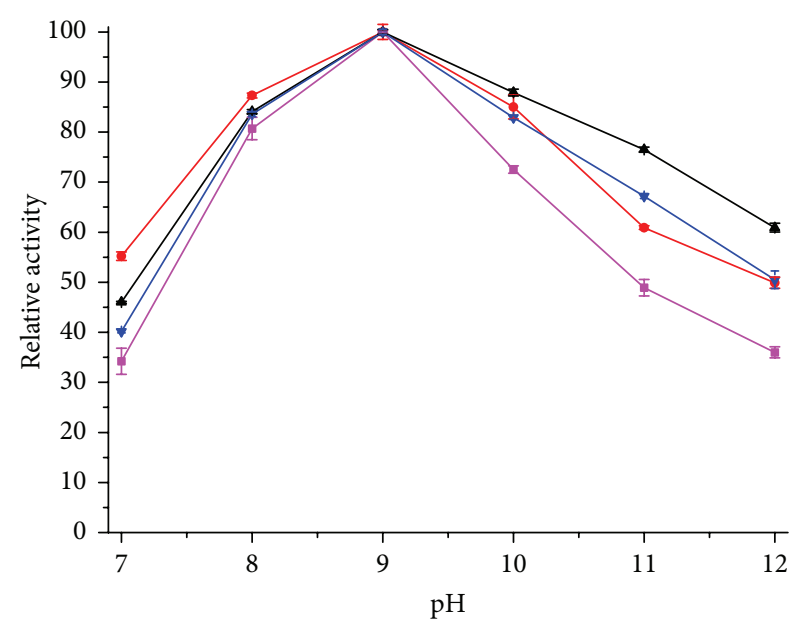

FIGURE 5: Optimal pH of immobilized enzyme. This figure shows the relationship between relative activity and $\mathrm{pH}$. The absolute values of hydrolytic activity: free lipase: $26.5 \mathrm{U} / \mathrm{mL}$; WDA: $373.2 \mathrm{U} / \mathrm{g}$; EP: $245.7 \mathrm{U} / \mathrm{g}$; EA: 172.6 U/g. The color of curves: magenta: free lipase; red: WDA; black: EP; blue: EA.

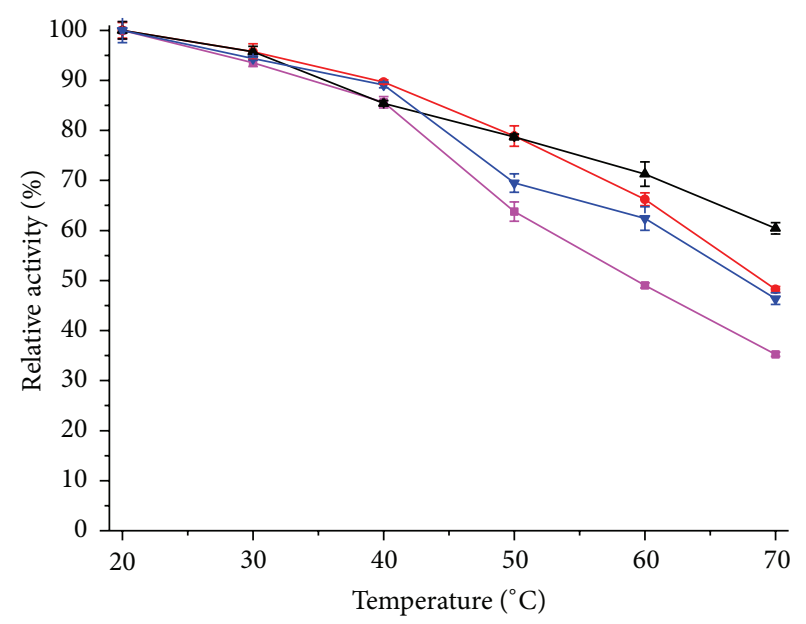

FIGURE 6: Thermal stability of free and immobilized enzyme. This figure shows the relationship between relative activity and temperature. The absolute values of hydrolytic activity: free lipase: 21.3 U/mL; WDA: $358.5 \mathrm{U} / \mathrm{g}$; EP: $231.4 \mathrm{U} / \mathrm{g}$; EA: 174.2 U/g. The color of curves: magenta: free lipase; red: WDA; black: EP; blue: EA.

$\mathrm{pH}$ stability assays of free and immobilized lipases were performed in the $\mathrm{pH}$ range $7-12$. The obtained results were shown in Figure 7. At alkaline $\mathrm{pH}$, immobilized lipases were more stable than free lipase (residue activity more than $63.4 \%$ at $\mathrm{pH} 11$ for $3 \mathrm{~h}$ ). Immobilization support could maintain the three-dimensional structure of lipase and resist the interference of high $\mathrm{pH}$.

3.4. Reusability of Immobilized Lipase. Immobilized lipases retained $80 \%$ of their activity after 5 cycles (Table 1 ). The results mean that the lipase is tightly attached to carriers in the recycling process without obviously losing activity. The residual activity of WDA and EP retained full activity $38.7 \%$ 
TABLE 1: Reusability of immobilized lipase.

\begin{tabular}{lccc}
\hline Cycle & $\begin{array}{c}\text { WDA } \\
\text { Relative activity } \\
(\%)\end{array}$ & $\begin{array}{c}\text { EP } \\
\text { Relative activity } \\
(\%)\end{array}$ & $\begin{array}{c}\text { EA } \\
\text { Relative activity } \\
(\%)\end{array}$ \\
\hline & $100( \pm 1.2)$ & $100( \pm 0.8)$ & $100( \pm 0.5)$ \\
1 & $($ Activity & $($ Activity & $($ Activity \\
& $365.9 \mathrm{U} / \mathrm{g})$ & $238.4 \mathrm{U} / \mathrm{g})$ & $173.8 \mathrm{U} / \mathrm{g})$ \\
2 & $92.3( \pm 0.3)$ & $95.1( \pm 1)$ & $98.0( \pm 0.9)$ \\
3 & $86.6( \pm 0.5)$ & $88.2( \pm 1.2)$ & $89.7( \pm 1.5)$ \\
4 & $82.3( \pm 2.1)$ & $84.9( \pm 1.8)$ & $89.4( \pm 1.9)$ \\
5 & $80.1( \pm 0.8)$ & $80.7( \pm 0.9)$ & $85.7( \pm 0.8)$ \\
6 & $69.5( \pm 1)$ & $73.6( \pm 0.7)$ & $82.1( \pm 0.7)$ \\
7 & $60.5( \pm 0.2)$ & $70.8( \pm 1.3)$ & $71.5( \pm 0.1)$ \\
8 & $52.4( \pm 0.1)$ & $67.8( \pm 0.6)$ & $63.1( \pm 1.4)$ \\
9 & $43.9( \pm 0.9)$ & $53.9( \pm 0.6)$ & $59.0( \pm 1.3)$ \\
10 & $38.7( \pm 0.5)$ & $48.1( \pm 0.8)$ & $52.1( \pm 0.2)$ \\
\hline
\end{tabular}

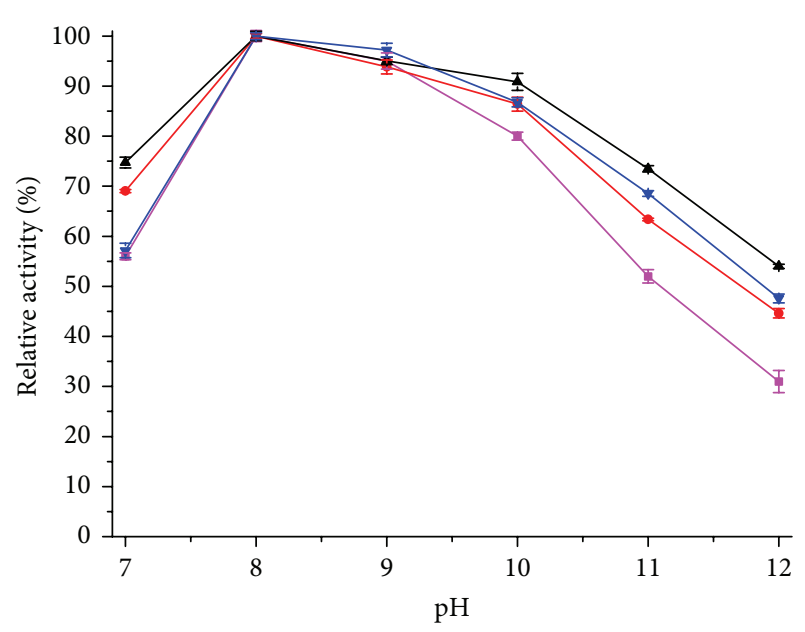

FIGURE 7: pH stability of free and immobilized enzyme. This figure shows the relationship between relative activity and $\mathrm{pH}$. The absolute values of hydrolytic activity: free lipase: $21.5 \mathrm{U} / \mathrm{mL}$; WDA: $362.1 \mathrm{U} / \mathrm{g}$; EP: $235.7 \mathrm{U} / \mathrm{g}$; EA: $170.3 \mathrm{U} / \mathrm{g}$. The color of curves: magenta: free lipase; red: WDA; black: EP; blue: EA.

and $48.1 \%$, respectively, after 10 cycles. The residual activity of EA retained $52.1 \%$ after 10 cycles because of its multipoint covalent attachment. WDA which is immobilized by the absorption method is significantly losing its activity because of the weak interaction. The residual activity of EP which is immobilized by adsorption and covalent attachment was between covalent linkage method and absorption method. Covalent linkage method showed better reusability because the stable chemical bond between enzyme and carrier increased the stability of immobilized enzyme.

3.5. Effect of Different Organic Solvents on the Catalytic Activity. The results are presented in Table 2. The activities of immobilized lipase were almost lost in chloroform, n-hexane, and $\mathrm{n}$-heptane. In ethanol and acetone, immobilized lipases could keep more than $47 \%$ activity, and the activity of WDA
TABLE 2: Effect of organic solvents on immobilized lipase activity.

\begin{tabular}{lccc}
\hline Type & WDA & EP & EA \\
Solvent & $\begin{array}{c}\text { Relative } \\
\text { activity }(\%)\end{array}$ & $\begin{array}{c}\text { Relative } \\
\text { activity }(\%)\end{array}$ & $\begin{array}{c}\text { Relative } \\
\text { activity }(\%)\end{array}$ \\
\hline Buffer & $100( \pm 0.3)$ & $100( \pm 1.4)$ & $100( \pm 1.2)$ \\
Ethanol & $77.7( \pm 0.2)$ & $47.0( \pm 0.7)$ & $68.7( \pm 1.2)$ \\
tert-Butanol & $156.6( \pm 0.5)$ & $108.7( \pm 2.4)$ & $114.8( \pm 2.3)$ \\
Acetone & $106.3( \pm 1.5)$ & $66.6( \pm 1.6)$ & $55.7( \pm 0.9)$ \\
Chloroform & $10.2( \pm 2.1)$ & $14.1( \pm 0.8)$ & $7.6( \pm 0.2)$ \\
n-Hexane & $15.1( \pm 1)$ & $30.5( \pm 1.8)$ & $20.0( \pm 0.8)$ \\
n-Heptane & $12.1( \pm 0.6)$ & $24.3( \pm 1.3)$ & $17.9( \pm 0.4)$ \\
\hline
\end{tabular}

in acetone increased to $106.3 \%$. tert-Butanol could increase the activity of immobilized lipase and the activity of WDA up to $156.6 \%$. In previous works, tert-butanol has been shown to stabilize the activity of Candida antarctica lipase [43-45]. tert-Butanol is not a substrate for lipase and is easily removed by washing step. These reasons may cause the enhancement of lipase activity by incubating in tert-butanol. Immobilized lipase catalyzed the interesterification and hydrolysis reaction of unsaturated fatty acid (such as fish oil) and tert-butanol often used as the reaction solvent. These immobilization methods increased or kept the stability of lipase in tertbutanol, ethanol, and acetone. It provides a chance to expand the application of marine lipase in organic system.

\section{Conclusion}

A microbial lipase immobilized by three carriers retained good activity at temperature $40^{\circ} \mathrm{C}$ and $\mathrm{pH} 9$. Immobilization of lipase expanded the application range of lipase to catalyze hydrolysis and esterification in harsh condition. It improved reusability of lipase and showed enhanced activity when exposed to tert-butanol. It provides a chance to expand the application of marine lipase in organic system.

\section{Conflict of Interests}

The authors declare that there is no conflict of interests regarding the publication of this paper.

\section{Acknowledgments}

This project was funded by "Immobilization and Application of Marine Low Temperature Lipase," ZQ51201415038, Qingdao Postdoctoral Researcher Applied Research Project, Qingdao, China; "Marine Drug and Biological Product," U1406402-5, National Science Foundation-Joint Fund, China; "Joint Research and Development of Marine Biological Enzyme Catalytic Function and Key Technology Application," 2014DFG30890, International Science and Technology Cooperation and Exchanges, China; and "China International Science and Technology Cooperation special items," 2011DFA32200. 


\section{References}

[1] M. Guncheva and D. Zhiryakova, "Catalytic properties and potential applications of Bacillus lipases," Journal of Molecular Catalysis B: Enzymatic, vol. 68, no. 1, pp. 1-21, 2011.

[2] R. Sharma, Y. Chisti, and U. C. Banerjee, "Production, purification, characterization, and applications of lipases," Biotechnology Advances, vol. 19, no. 8, pp. 627-662, 2001.

[3] P.-Y. Stergiou, A. Foukis, M. Filippou et al., "Advances in lipasecatalyzed esterification reactions," Biotechnology Advances, vol. 31, no. 8, pp. 1846-1859, 2013.

[4] S. Elgue, A. Conté, A. Marty, and J.-S. Condoret, "Continuous lipase esterification using process intensification technologies," Journal of Chemical Technology and Biotechnology, vol. 89, no. 10, pp. 1590-1598, 2014.

[5] E. Séverac, O. Galy, F. Turon et al., "Selection of CalB immobilization method to be used in continuous oil transesterification: analysis of the economical impact," Enzyme and Microbial Technology, vol. 48, no. 1, pp. 61-70, 2011.

[6] E. Jenab, F. Temelli, and J. M. Curtis, "Lipase-catalysed interesterification between canola oil and fully hydrogenated canola oil in contact with supercritical carbon dioxide," Food Chemistry, vol. 141, no. 3, pp. 2220-2228, 2013.

[7] F. Hasan, A. A. Shah, and A. Hameed, "Industrial applications of microbial lipases," Enzyme and Microbial Technology, vol. 39, no. 2, pp. 235-251, 2006.

[8] N. Dizge, C. Aydiner, D. Y. Imer, M. Bayramoglu, A. Tanriseven, and B. Keskinler, "Biodiesel production from sunflower, soybean, and waste cooking oils by transesterification using lipase immobilized onto a novel microporous polymer," Bioresource Technology, vol. 100, no. 6, pp. 1983-1991, 2009.

[9] T. Tan, J. Lu, K. Nie, L. Deng, and F. Wang, "Biodiesel production with immobilized lipase: a review," Biotechnology Advances, vol. 28 , no. 5, pp. 628-634, 2010.

[10] H. T. Hwang, F. Qi, C. Yuan et al., "Lipase-catalyzed process for biodiesel production: protein engineering and lipase production," Biotechnology and Bioengineering, vol. 111, no. 4, pp. 639-653, 2014.

[11] C. D. Anobom, A. S. Pinheiro, R. A. De-Andrade et al., "From structure to catalysis: recent developments in the biotechnological applications of lipases," BioMed Research International, vol. 2014, Article ID 684506, 11 pages, 2014.

[12] D. M. Solano, P. Hoyos, M. J. Hernáiz, A. R. Alcántara, and J. M. Sánchez-Montero, "Industrial biotransformations in the synthesis of building blocks leading to enantiopure drugs," Bioresource Technology, vol. 115, pp. 196-207, 2012.

[13] S. Zhu, Y. Wu, and Z. Yu, "Immobilization of Candida rugosa lipase on a $\mathrm{pH}$-sensitive support for enantioselective hydrolysis of ketoprofen ester," Journal of Biotechnology, vol. 116, no. 4, pp. 397-401, 2005.

[14] M. Nerurkar, M. Joshi, S. Pariti, and R. Adivarekar, "Application of lipase from marine bacteria Bacillus sonorensis as an additive in detergent formulation," Journal of Surfactants and Detergents, vol. 16, no. 3, pp. 435-443, 2013.

[15] Y. Yan, X. Zhang, and D. Chen, "Enhanced catalysis of Yarrowia lipolytica lipase LIP2 immobilized on macroporous resin and its application in enrichment of polyunsaturated fatty acids," Bioresource Technology, vol. 131, pp. 179-187, 2013.

[16] L. Cao, "Immobilised enzymes: science or art?" Current Opinion in Chemical Biology, vol. 9, no. 2, pp. 217-226, 2005.

[17] E. Biró, A. S. Németh, C. Sisak, T. Feczkó, and J. Gyenis, "Preparation of chitosan particles suitable for enzyme immobilization,"
Journal of Biochemical and Biophysical Methods, vol. 70, no. 6, pp. 1240-1246, 2008.

[18] A. Manrich, C. M. A. Galvão, C. D. F. Jesus, R. C. Giordano, and R. L. C. Giordano, "Immobilization of trypsin on chitosan gels: use of different activation protocols and comparison with other supports," International Journal of Biological Macromolecules, vol. 43, no. 1, pp. 54-61, 2008.

[19] N. Ž. Prlainović, Z. D. Knežević-Jugović, D. Ž. Mijin, and D. I. Bezbradica, "Immobilization of lipase from Candida rugosa on Sepabeads: the effect of lipase oxidation by periodates," Bioprocess and Biosystems Engineering, vol. 34, no. 7, pp. 803810, 2011.

[20] S. Cesarini, B. Infanzón, F. I. J. Pastor, and P. Diaz, "Fast and economic immobilization methods described for non-commercial Pseudomonas lipases," BMC Biotechnology, vol. 14, article 27, 2014.

[21] T.-C. Hung, R. Giridhar, S.-H. Chiou, and W.-T. Wu, "Binary immobilization of Candida rugosa lipase on chitosan," Journal of Molecular Catalysis B: Enzymatic, vol. 26, no. 1-2, pp. 69-78, 2003.

[22] X. Meng, G. Xu, Q.-L. Zhou, J.-P. Wu, and L.-R. Yang, "Highly efficient solvent-free synthesis of 1,3-diacylglycerols by lipase immobilised on nano-sized magnetite particles," Food Chemistry, vol. 143, pp. 319-324, 2014.

[23] M. B. Ansorge-Schumacher and O. Thum, "Immobilised lipases in the cosmetics industry," Chemical Society Reviews, vol. 42, no. 15, pp. 6475-6490, 2013.

[24] S. Nisha, S. A. Karthick, and N. Gobi, "A review on methods, application and properties of immobilized enzyme," Chemical Science Review and Letters, vol. 1, no. 3, pp. 148-155, 2012.

[25] R. Prodanović, S. Jovanović, and Z. Vujčić, "Immobilization of invertase on a new type of macroporous glycidyl methacrylate," Biotechnology Letters, vol. 23, no. 14, pp. 1171-1174, 2001.

[26] K. Hernandez, C. Garcia-Galan, and R. Fernandez-Lafuente, "Simple and efficient immobilization of lipase B from Candida antarctica on porous styrene-divinylbenzene beads," Enzyme and Microbial Technology, vol. 49, no. 1, pp. 72-78, 2011.

[27] N. R. Mohamad, N. A. Buang, N. A. Mahat et al., "A facile enzymatic synthesis of geranyl propionate by physically adsorbed Candida rugosa lipase onto multi-walled carbon nanotubes," Enzyme and Microbial Technology, vol. 72, pp. 49-55, 2015.

[28] G. Bayramoğlu, M. Yılmaz, A. Ü. Şenel, and M. Y. Arıca, "Preparation of nanofibrous polymer grafted magnetic poly(GMAMMA)-g-MAA beads for immobilization of trypsin via adsorption," Biochemical Engineering Journal, vol. 40, no. 2, pp. 262274, 2008.

[29] J. M. Palomo, G. Muñoz, G. Fernández-Lorente, C. Mateo, R. Fernández-Lafuente, and J. M. Guisán, "Interfacial adsorption of lipases on very hydrophobic support (octadecylSepabeads): immobilization, hyperactivation and stabilization of the open form of lipases," Journal of Molecular Catalysis B: Enzymatic, vol. 19-20, pp. 279-286, 2002.

[30] A. Sassolas, L. J. Blum, and B. D. Leca-Bouvier, "Immobilization strategies to develop enzymatic biosensors," Biotechnology Advances, vol. 30, no. 3, pp. 489-511, 2012.

[31] N. Ghattas, F. Abidi, S. Galai, M. N. Marzouki, and A. B. Salah, "Monoolein production by triglycerides hydrolysis using immobilized Rhizopus oryzae lipase," International Journal of Biological Macromolecules, vol. 68, pp. 1-6, 2014. 
[32] C. Bernal, P. Urrutia, A. Illanes, and L. Wilson, "Hierarchical meso-macroporous silica grafted with glyoxyl groups: opportunities for covalent immobilization of enzymes," New Biotechnology, vol. 30, no. 5, pp. 500-506, 2013.

[33] B. Krajewska, "Application of chitin- and chitosan-based materials for enzyme immobilizations: a review," Enzyme and Microbial Technology, vol. 35, no. 2-3, pp. 126-139, 2004.

[34] U. Guzik, K. Hupert-Kocurek, and D. Wojcieszynska, "Immobilization as a strategy for improving enzyme propertiesapplication to oxidoreductases," Molecules, vol. 19, no. 7, pp. 8995-9018, 2014.

[35] J. Sheng, F. Wang, H. Y. Wang, and M. Sun, "Cloning, characterization and expression of a novel lipase gene from marine psychrotrophic Yarrowia lipolytica," Annals of Microbiology, vol. 62, no. 3, pp. 1071-1077, 2012.

[36] C. Mateo, O. Abian, R. Fernandez-Lafuente, and J. M. Guisan, "Increase in conformational stability of enzymes immobilized on epoxy-activated supports by favoring additional multipoint covalent attachment," Enzyme and Microbial Technology, vol. 26, no. 7, pp. 509-515, 2000.

[37] C. Mateo, V. Grazu, J. M. Palomo, F. Lopez-Gallego, R. Fernandez-Lafuente, and J. M. Guisan, "Immobilization of enzymes on heterofunctional epoxy supports," Nature Protocols, vol. 2, no. 5, pp. 1022-1033, 2007.

[38] J. M. Bolivar, C. Mateo, V. Grazu, A. V. Carrascosa, B. C. Pessela, and J. M. Guisan, "Heterofunctional supports for the one-step purification, immobilization and stabilization of large multimeric enzymes: amino-glyoxyl versus amino-epoxy supports," Process Biochemistry, vol. 45, no. 10, pp. 1692-1698, 2010.

[39] S. Pahujani, S. S. Kanwar, G. Chauhan, and R. Gupta, "Glutaraldehyde activation of polymer Nylon-6 for lipase immobilization: enzyme characteristics and stability," Bioresource Technology, vol. 99, no. 7, pp. 2566-2570, 2008.

[40] D. S. Rodrigues, A. A. Mendes, W. S. Adriano, L. R. B. Gonçalves, and R. L. C. Giordano, "Multipoint covalent immobilization of microbial lipase on chitosan and agarose activated by different methods," Journal of Molecular Catalysis B: Enzymatic, vol. 51, no. 3-4, pp. 100-109, 2008.

[41] J. A. Silva, G. P. Macedo, D. S. Rodrigues, R. L. C. Giordano, and L. R. B. Gonçalves, "Immobilization of Candida antarctica lipase B by covalent attachment on chitosan-based hydrogels using different support activation strategies," Biochemical Engineering Journal, vol. 60, pp. 16-24, 2012.

[42] O. Barbosa, C. Ortiz, Á. Berenguer-Murcia, R. Torres, R. C. Rodrigues, and R. Fernandez-Lafuente, "Glutaraldehyde in biocatalysts design: a useful crosslinker and a versatile tool in enzyme immobilization," RSC Advances, vol. 4, no. 4, pp. 15831600, 2014.

[43] J.-W. Chen and W.-T. Wu, "Regeneration of immobilized Candida antarctica lipase for transesterification," Journal of Bioscience and Bioengineering, vol. 95, no. 5, pp. 466-469, 2003.

[44] L. Li, W. Du, D. Liu, L. Wang, and Z. Li, "Lipase-catalyzed transesterification of rapeseed oils for biodiesel production with a novel organic solvent as the reaction medium," Journal of Molecular Catalysis B: Enzymatic, vol. 43, no. 1-4, pp. 58-62, 2006.

[45] D. Royon, M. Daz, G. Ellenrieder, and S. Locatelli, "Enzymatic production of biodiesel from cotton seed oil using t-butanol as a solvent," Bioresource Technology, vol. 98, no. 3, pp. 648-653, 2007. 

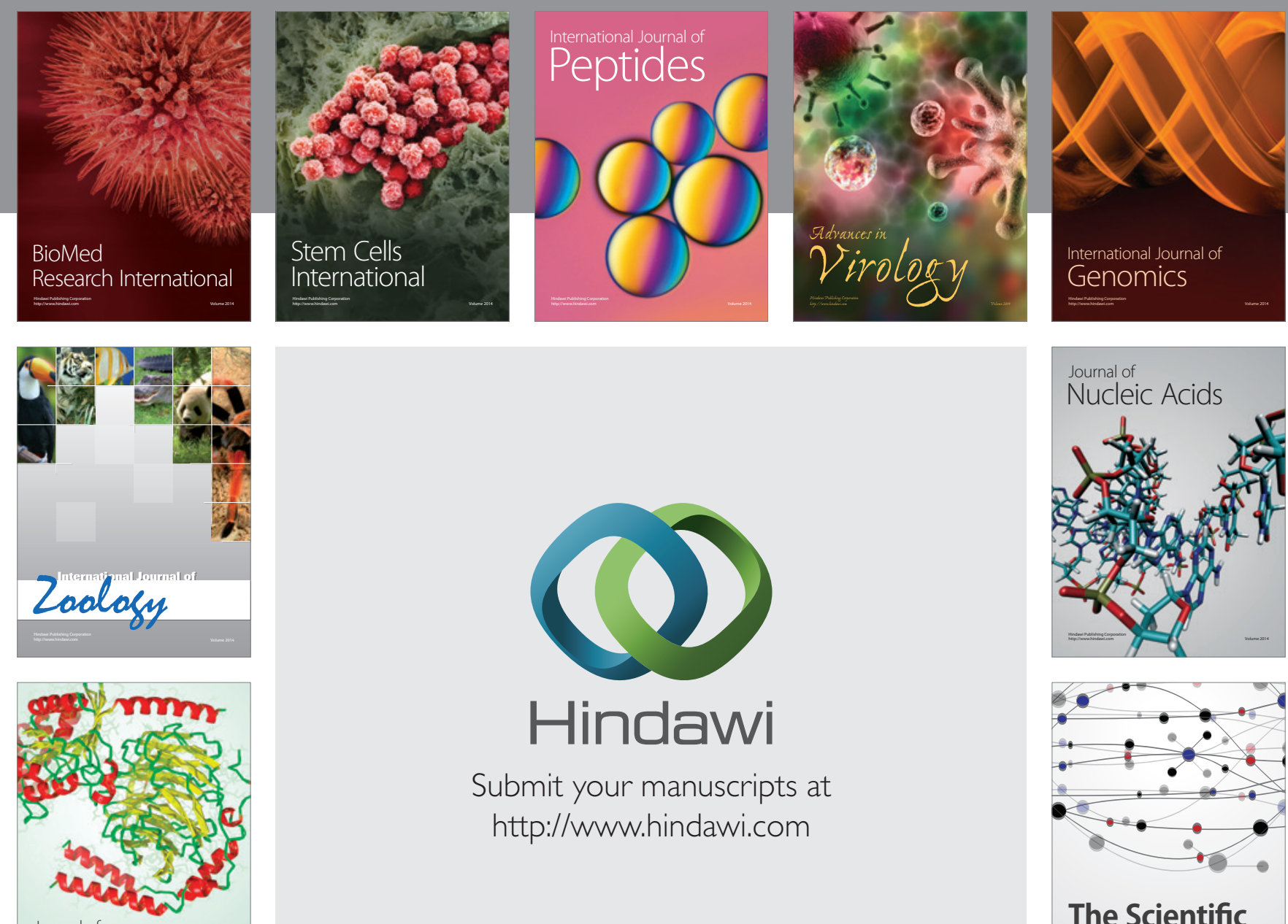

Submit your manuscripts at

http://www.hindawi.com

Journal of
Signal Transduction
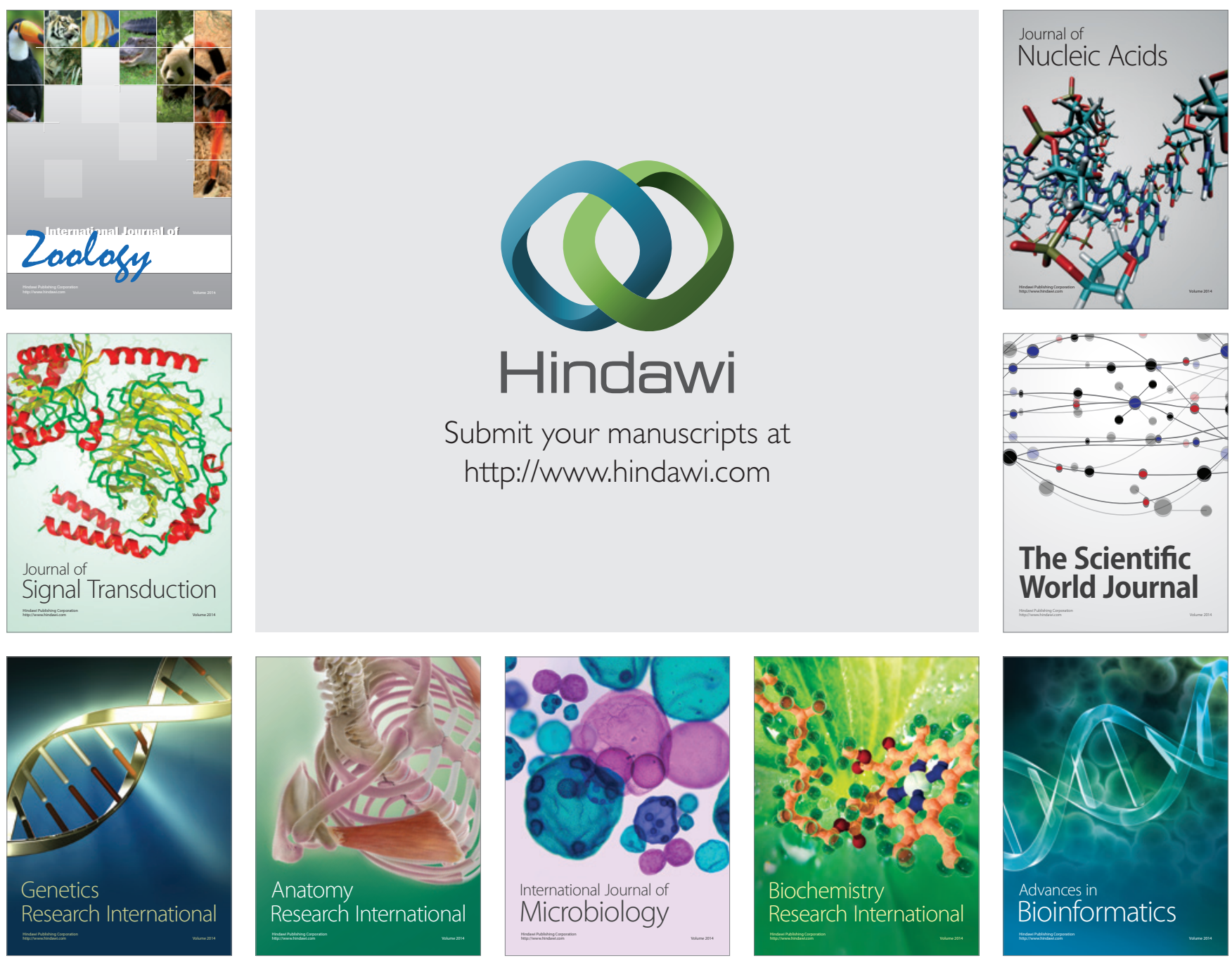

The Scientific World Journal
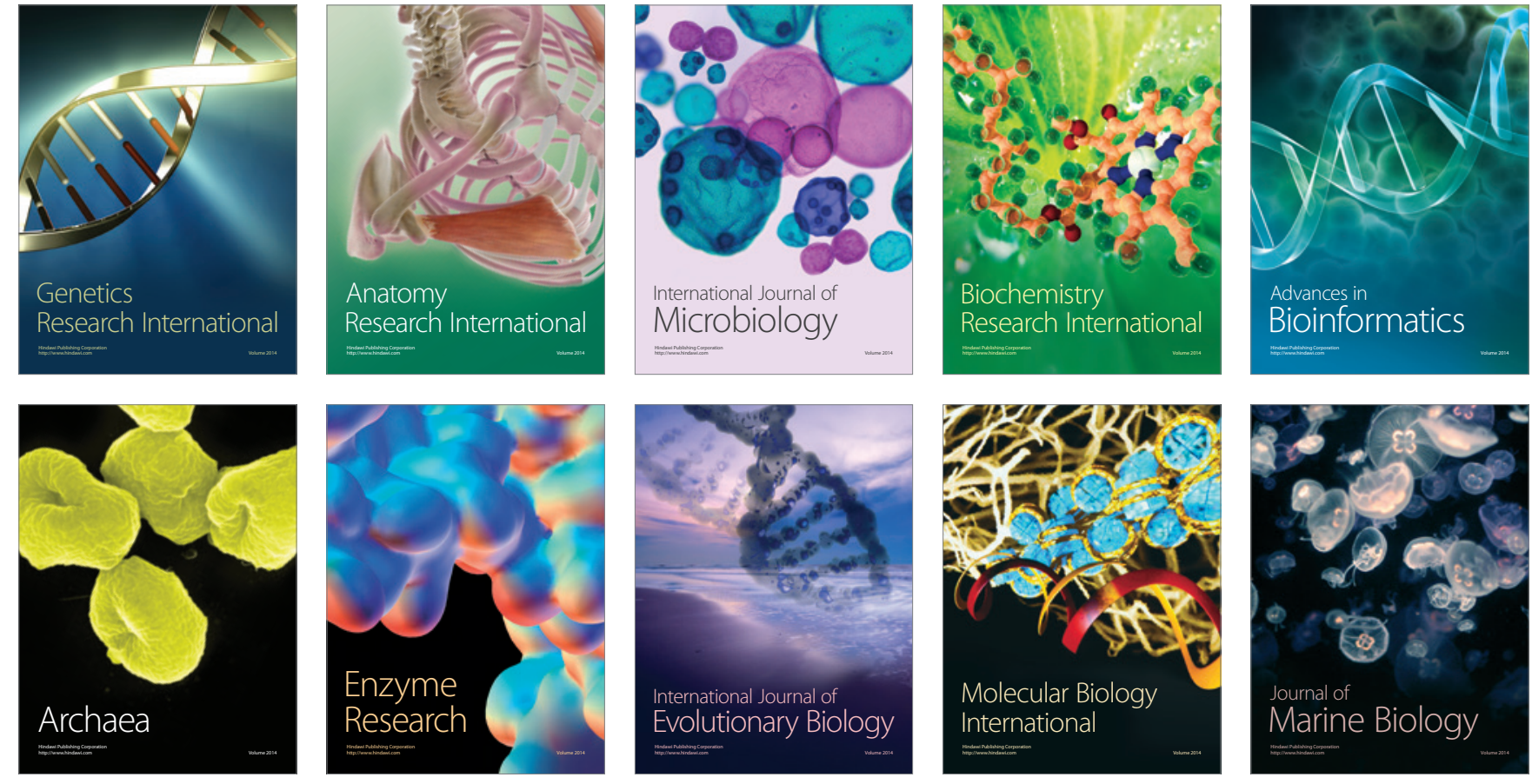